\title{
Una suerte de calma hechizada. Praxis de extrañamiento y trascendencia poética (Paseando por el Rastro con Gómez de la Serna)
}

\author{
A sort of enchanted calm. \\ Praxis of estrangement and poetic transcendence \\ (Walking along the «Rastro» \\ with Gómez de la Serna)
}

\author{
CÉSAR MORENO-MÁRQUEZ \\ Universidad de Sevilla (España)
}

Recibido: 14-XII-2015 Aceptado: 27-XII-2015

\begin{abstract}
RESUMEN
El presente artículo se propone indagar en la praxis de extrañamiento que lleva acabo Gómez de la Serna en El Rastro (1914), praxis que será esencial de cara a comprender uno de los vectores fundamentales de la (ulterior) objetología surrealista. Dicha praxis comprende al menos ocho prácticas o posibilidades de deshacer que afectan al Límite (que discrimina y jerarquiza), al Futuro (ingenuo y dictatorial), a la familiaridad hogareña burguesa (que encarcela y amodorra), a la funcionalidad utilitaria (que banaliza), a la idealidad falsa (de los prestigios de la ciudad), a la propiedad (de nuestras cosas), a uno mismo (praxis de desasimiento), y al propio texto. Estas prácticas configuran un extrañamiento masivo, aunque sereno, con una clara proyección de trascendencia poética, existencial y metafísica.
\end{abstract}

(C) Contrastes. Revista Internacional de Filosofia, vol. XXI-Nº3 (2016), pp. 73-94. ISSN: 1136-4076 Departamento de Filosofía, Universidad de Málaga, Facultad de Filosofía y Letras Campus de Teatinos, E-29071 Málaga (España) 


\title{
PALABRAS CLAVE
}

ESTRAÑAMIENTO, POÉTICA, SURREALIDAD, RAMÓN GÓMEZ DE LA SER-

NA, RASTRO

\begin{abstract}
This article aims to look into the practice of estrangement that Gómez de la Serna carries out in The madrilenian Flea-Market (El Rastro, 1914), practice that will be essential in order to understand one of the key vectors of the (subsequent) surrealistic Objectology. Such practice involves at least eight practices or possibilities of undoing that concern the Limit (which discriminates and organizes into a hierarchy), the Future (ingenuous and dictatorial), the bourgeois familiarity of home (which imprisons and causes drowsiness), the useful functionality (which trivialises), the false ideality (of prestiges of the city), the property (of our things), to oneself (practice of release) and the text itself. These practices constitute a massive although serene estrangement, with a clear projection of poetical, existential and metaphysical transcendency. KEYWORDS

ESTRANGEMENT, POETICS, SURREALITY, RAMÓN GÓMEZ DE LA SERNA, THE MADRILENIAN FLEA-MARKET
\end{abstract}

«Cuánto espacio interior para el baile íntimo»

(Gómez de la Serna 1998, 212)

CREO QUE A ESTAS ALTURAS no podría ponerse en duda que una de las grandes aportaciones de lo que llamamos arte contemporáneo ha sido, y es de desear que siga siendo, la de convencernos de que hoy el prestigio del arte no radica, sobre todo, en dejarnos boquiabiertos ante una extraordinaria manifestación de lo que suele llamarse belleza, sino en auxiliarnos en una experiencia tan decisiva como la del extrañamiento, que por su propia idiosincrasia parece que no se presta, sin más, a ser algo que suceda espontáneamente, con la frecuencia e intensidad que sería deseable, pero tampoco, se dirá, a que sea una experiencia preparada, encauzada o incluso organizada (casi metódica), lo que podría hacernos creer que el extrañamiento al que pudiera accederse por este medio sería demasiado «artificial», meramente simulado y de escaso valor. Sin embargo, es privilegio de lo que llamamos «arte», entre otros muchos, el permitirnos microexperiencias o experimentaciones muy eficaces en tal sentido. Es precisamente desde esta perspectiva como podríamos comprender muchas prácticas y juegos de las vanguardias como propuestas a favor de lo que Ernst Jünger llamaba la apertura de vías contra nuestro usual amodorramiento en cientos de rutinas invasivas, prejuicios cotidianos virales y, por supuesto, nuestra sempetirna pereza de andar por casa.

Es en tal sentido (el de la apertura de vías) en el que se propone aquí un acercamiento a El Rastro, de Ramón Gómez de la Serna (en adelante: GS) de 
1914 (GS 1998), ${ }^{1}$ que podría ser comprendido justamente como el memorandum íntimo de los paseos y experiencias del genial escritor madrileño por el espaciotiempo del Rastro a fin de alcanzar desde diferentes aspectos, que quisiera comentar brevemente, estímulos facilitadores o aceleradores para la praxis de extrañamiento imprescindible a la trascendencia poética, tomando como guía indiscutible las cosas del Rastro, en un clarísimo antecedente de lo que en pocos años será uno de los ámbitos predilectos de la objetología surrealista. ${ }^{2}$

En un conocido pasaje de Nadja, André Breton narra cómo había visitado recientemente el Mercado de las Pulgas de Saint-Ouen, en París, al que iba a menudo «buscando esos objetos que no se encuentran en ningún otro sitio, pasados de moda, rotos, inutilizables, casi incomprensibles, perversos, en último término, en el sentido en que lo entiendo y me gusta» (Breton 1997, 138). Pocos años antes se había referido a un extraño objet trouvé cuando, en sueños, paseaba por un mercado de Saint-Malo. Decía entonces que a fin de favorecer en algunas personas la conciencia fetichista de que «así ha sucedido» referido a lo inverosímil del testimonio poético, se proponía «fabricar, en la medida de lo posible, algunos de esos objetos a los que uno se acerca sólo en el sueño y que no parecen defendibles ni bajo el concepto de la utilidad ni bajo el del entretenimiento» (Breton 1974, 20). Y se preguntaba poco después:

¿Será acaso el destino inmediato de las creaciones poéticas el adquirir ese carácter tangible, el desplazar tan singularmente las fronteras de lo supuestamente real? [...] Falta mucho para que el Dios que nos habita guarde el reposo del séptimo día. Todavía estamos leyendo las primeras páginas del Génesis. Tan sólo depende de nosotros que echemos sobre las ruinas del antiguo mundo las bases de nuestro nuevo paraíso terrenal [...]. El peligro en que nos pone la razón, en el sentido más general y discutible de la palabra, al someter las obras del espíritu a sus dogmas irreversibles, al quitarnos de hecho la posibilidad de elegir el modo de expresión que nos perjudique menos, ese peligro, sin duda, dista mucho de ser descartado. Los inspectores lamentables, que no nos sueltan al salir de la escuela, siguen haciendo sus giras de inspección en nuestras casas, en nuestra vida. Se cercioran de que seguimos llamando a un gato un gato y, como al fin de cuentas conservamos la serenidad, no nos recluyen obligatoriamente en asilos y cárceles (Breton 1974, 20-21).

1 Al final del volumen figura un Apéndice (pp. 701-797). En cierto modo al menos, esta contribución complementa a Moreno 2014. Cf. González Alvarez 2002.

2 Me parece imprescindible recomendar el magnífico estudio de Puelles 2002. 
Si recuerdo aquí estas palabras de Breton es porque no debemos olvidar que todo lo que se pareciera, en cualquier ciudad (GS 1998, 73-74), a esa sui generis apoteosis de lo heteróclito que es el espacio del Rastro, ${ }^{3}$ ya desde 19131914 había sido explorado por GS en todas sus superficies y entrañas, en un ejercicio a pie de calle, por lo demás, de genuina etnografía chez nous (Clifford 1995) en el que la fidelidad descriptiva (sin pretensiones de «objetividad») se combinaba con la más extrema finesse poética. Años más tarde, los surrealistas entronizarán ese espacio urbano que en cualquier ciudad europea suponía lo mismo que el Rastro para Madrid: un país de Jauja objetológico (Puelles 2002, 23) para invitarnos a convertir en extraño lo familiar, a contracorriente de toda la energía que solemos invertir cotidianamente en tornar familiar lo extraño (Clifford 1995, 179). ${ }^{4}$ Espacio idóneo como pocos para una praxis de extrañamiento sin ostentación ni aspavientos, eminentemente pensativa (como al estilo del efecto-extrañamiento brechtiano), aunque no por ello menos demoledora. Más allá de su inmediata funcionalidad, el Rastro era para GS sobre todo un inmenso laboratorio poético para «muchos días de nuevas idas solitarias» (GS 1998 , 77), pero también un campo de pruebas sobre todo existencial, en la medida en que el Rastro resultaba ser, contra lo que podría esperarse en primera instancia, una suerte de tónico o lanzadera del ánimo, una purga ideal (GS $1998,75)$ o la oportunidad para alcanzar un cierto consuelo y fortaleza ${ }^{5}$ frente a la apesadumbrada sensación de alienación cotidiana. A tal fin, GS construye la figura de los jóvenes íntegros como «traseúntes supuestos» del Rastro, en medio de la presunta decrepitud de las cosas, curtidos contra todo lo ruin en el ser humano y frente la ciudad y sus falsos prestigios (GS 1998, 213-218).

Se trata de las cosas, de salvarnos en ellas (Moreno 2014) ${ }^{6}$ y confiarles el

3 Digo «espacio del Rastro» porque me resultaría imposible olvidar (y aprovecho para homenajearlo aquí) ese hermano menor - pero también genial- del texto de GS que es Goytisolo 1988.

4 No estoy de acuerdo en asimilar el paso de lo extraño a lo familiar al «humanismo antropológico». Tampoco estoy de acuerdo, pero nos llevaría muy lejos y nos entretendría mucho comentarlo, con Novalis, cuando decía que la tarea de la Filosofía era hacernos sentir en todas partes como en casa. Lo dejaremos para otra ocasión.

5 Cf. también el importante parágrafo XII del Prólogo, en el que se afirma El Rastro como «un libro enérgico, condensado, reconcentrado, apaciguador, y en él todo está dicho con gusto de la palabra y de la imagen, en un esparcimiento lúbrico y extremado». Está hecho, sigue diciendo, «con la intención de envalentonar, de hacer que se crezcan los que lo lean, de hacerles aventurados y sonrientes, de hacerles impertérritos y asentados [...] sin falsos pucheros de visita de pésame, sin luto ninguno». Y concluye el parágrafo: «El objeto y sus greguerías: el objeto y su nimbo estricto. El objeto espontáneo, crudo, plástico, cínico, abundante, irónico, animoso hasta la muerte y bastándose a sí mismo» (GS 1998, 83).

6 La praxis de extrañamiento ramoniana se deja comprender desde el programa 
verbo y la metáfora. Pero, sobre todo, se trata de nosotros, junto con GS, en tanto consintamos en ser rescatados de una zona que si bien es perfectamente válida e incluso muy llevadera para las exigencias básicas y requerimientos elementales de nuestra vida ordinaria, con sus más que sensatas tramas de argumentos, afectos, intereses y propósitos de andar por casa, sin embargo, resulta muy precaria en el orden de la creatividad, pues en él rige una utilitarísima mera-identidad $(\mathrm{A}=\mathrm{A})$ empobrecedora y avariciosa, que tiende a imponer dictatorialmente que las cosas son lo que son, ni más ni menos, y que dan de sí lo que dan, y punto, en el horizonte mostrenco de un «al pan pan y al vino vino» tan socorrido como aburrido y aplanante. Cuando esa mera identidad se encarna en un circunmundo y cotidianeidad familiares y entrañables, la posibilidad del extrañamiento se torna menos abstracta y más estimulante. Es en este sentido como el paseo por el Rastro madrileño otorga la ocasión para un extrañamiento masivo, a las puertas de la eclosión de los objetos surreales, mucho antes de que André Breton en 1935, a la vista de su proliferación e indeterminación intrínseca, sugiriese que se los etiquetara como tales (Breton 1992, 276-277). A la altura de 1913-1914, todo era más genuino y espontáneo, incluso diría que más castizo y a ras de tierra, sin que ello impidiera que las cosas resplandeciesen abundantísimas, extrañas y fascinantes, insinuantes y misteriosas, crueles y lúcidas, aún sin la exigencia o la responsabilidad del prestigio (y sin la potencial mistificación) de «vanguardia» alguna, en una zona de tránsito entre el Escaparate-Hogar y el Basurero. Sin manifiesto ni pose, a GS le bastó su genio y la entrega apasionada a lo que en 1934 llamará la «vida incesante y sidérea en el éxtasis de los objetos» (GS 1988-4, 173). ${ }^{7}$

\section{DESLIMITACIÓN. LA TOTALIDAD LIBERADA, O LA ARRIBADA DE TODO}

\section{(APERTURA Y ACOGIDA)}

La primera praxis es de des-limitación. Como expresión urbana de Apei$r o n^{8}$, el Rastro acredita una cierta perspectiva de Totalidad no tanto en el

orteguiano de erótica filosófica. La tarea consistía, decía Ortega, en «dado un hecho -un hombre, un libro, un cuadro, un paisaje, un error, un dolor-, llevarlo por el camino más corto a la plenitud de su significado» (Ortega y Gasset 2004, 747).

7 Para él, lo decisivo era convertirse uno mismo en cosa, sin importar cuál. Decía GS que «las cosas siempre han sido para mí ostensorios de la fuerza cohesiva del mundo en el que es indiferente ser una cosa u otra. Igual me daba ser tintero, que jaula, que bola de cristal. [...] Un tarugo de madera, un gran clavo, un cenicero, son elementos filosofales, claves de universo, sino que guardando la incógnita suprema de por qué lo son. Para mí es astrolabio cualquier cosa pequeña, un enchufe desprendido, un salero cipotal» (GS 1988-4, 174-175).

8 Sería demasiado complicado entrar en detalles. Básicamente, apeiron es toma- 
sentido de agrupación y síntesis, cuanto de apertura-y-acogida sin cortapisas ni criterio discriminador. Cuando GS acude al Rastro, es a la búsqueda de un Encuentro sin condiciones. Paseando por sus tiendas, tenderetes y cuchitriles, dejándose cautivar por sus ambientes y sus gentes, no es necesario ni el ente en total que invita a filosofar con altanería, metafísicamente, ni la imaginación imposible del todo del ente (Heidegger 2000, 98 y ss.). Como espacio heteróclito, el Rastro ayuda a intuir «cualquier cosa», y cualquier-cosa ya conduce, por su indeterminada singularidad, a Todo y a la arribada de Todo. Lo decisivo es que sea cualquiera... y entonces no se tratará sólo del Todo como cantidad, sino de la Cosa, de su extraño y sereno esplendor antes de que se reparta o escinda en esto o aquello, acorde con nuestro terco afán discriminador y clasificatorio. Una Totalidad aireada por completo, liberada de norma y criterio, con razón podría parecernos «una locura», por lo que no sería descabellado considerar que bastaría un poco más de pérdida de sentido para que al lector de El Rastro pudiese parecerle que nos encontramos a un paso tan sólo del continuum que el poema dadá o la escritura automática pretenderán en breve explorar (Blanchot 1970, 35).

A la altura de 1913-1914, a GS le basta el intenso sentimiento vital y de transgresión de la vanguardia futurista de aquellos años y su excitada hospitalidad respecto a lo arribante (Derrida 1994). ${ }^{9}$ Esta experiencia indica que lo que haya de presentarse a la vuelta de la esquina podrá ser (iy es mejor que sea!) inesperado y extraño. No olvidemos, por cierto, que cuando GS publica El Rastro, un tal Duchamp, tan sólo un año de edad mayor, compra un portabotellas en el Bazar de l'Hôtel de Ville de Paris. Sin duda, 1914 va a ser un año excelente para las cosas, porque se trata no sólo de las cosas sin más, sino de la Coseidad en su salvaje indiferencia, que la tornará extrañamente prestigiosa no por otra razón que por ser la verdad de la Cosa: valiosa por sí misma y sorprendente. Entre Duchamp y GS forman un tándem irrepetible (Moreno 2014). Por cierto, el recorrido que hizo el portabotellas de Duchamp, poco tiempo después, desde su piso en París al basurero ${ }^{10}$ (pues su hermana

do aquí en el sentido de una praxis de des-limitación que podría extraerse de algunas consideraciones de Martin Heidegger respecto al Apeiron de Anaximandro (Heidegger 1981, 112-113). Quizás pudiera resultar interesante, para, por ejemplo, comprobar la conexión entre la fuerza des-limitadora del Apeiron y la revolución deslimitadora de la música en el siglo XX (Moreno 2012, 202-204).

9 Con permiso de Derrida, de quien tomo el término (aunque GS habla expresamente de la arribada de todo).

10 En una de sus cartas (de 1882) confesaba Vincent Van Gogh: «esta mañana visité el lugar donde los barrenderos amontonan la basura. ¡dios mío, qué bello era! mañana van a sacar un par de interesantes piezas de ese montón de basura, incluyendo unas farolas rotas, para que yo las admire y, si quiero, para usarlas como modelos. [...] 
lo tiró pensando que no servía para nada (Tomkins 1999, 176-177), lo realiza imaginariamente GS. La historia de sus cosas comienza allí donde casi fue a parar el objet trouvé/ready made duchampiano. Pero el Rastro, claro está, no es mero bazar, ni hogar ni basurero.

Lo extraño es garantía in extremis de totalidad y de que nuestra apertura es incondicionada e irrestricta, como la que imaginaba Montaigne que tendría Dios para con los monstruos, o la que él mismo tenía para con los milagros (Montaigne 1984). ${ }^{11}$ El Rastro se parece, en este sentido, a un Cabinet de Curiosités o a una Wunderkammer [cámara de maravillas] nada académica ni principesca, sino más bien urbana y barriobajera. Todo podría encontrarse en la ingente menudencia del Rastro. Su ética vital es la omniadmisibilidad a ultranza. Por ejemplo, incluso hay un coche familiar, pero podría haber también un aeroplano, y «estaría bien hallar un barco para completar la lección inaudita del Rastro» (GS 1998, 187). Atención, sin embargo: ese Todo se basta y sobra con las cosas reales. A GS sólo le interesa la realidad más estricta, ${ }^{12}$ si bien no sólo lo real fáctico de hecho, sino todo lo real-posible, que no se debe confundir con lo fantástico. Uno de los momentos culminantes de El Rastro es el capítulo dedicado a Lo posible, expresión renovada de «la arribada de todo», la «gran mescolanza de todo» y el «montón de cosas» (GS 1998; 98, 99, 103). Así, entre las cosas reales extraordinarias y extrañas se podría encontrar

la dentadura sarcástica de Schopenhauer, el manuscrito que perdió Oscar Wilde en un coche y del que no pudo saberse nada, bártulos, vestigios personales de personajes de las novelas, las cosas, por ejemplo, de aquel investigador de lo absoluto de la novela de Balzac, cosas de los personajes de Dickens y de sus casas, todas las cosas que tenía en su desván el viejecito del Pato Silvestre de Ibsen, el cuervo de Poe disecado y silencioso, etcétera, etc. (GS 1998, 156).

ese lugar muy bien podría ser tema para un cuento de hadas de Andersen, esa concentración de basuras, botes, canastas, cacharros, cuencos, jarros metálicos, alambres, linternas, pipas, tubos de lámparas y cañones de chimenea que la gente tira. realmente creo que esta noche soñaré con ese sitio, y en el invierno tendré mucho que hacer con todo eso en mi obra [...] sería un verdadero placer llevarte allí, y a otros lugares que son un auténtico paraíso para el artista, por muy feos que sean» (cit. por Hughes 2000, 63).

11 Cf. los capítulos XXVI del Libro I («De la locura que hay en someter lo verdadero y lo falso al juicio de nuestra suficiencia») y XXX del Libro II («De un niño monstruoso»).

12 Para Puelles, «el surrealismo no es un irrealismo, sino un realismo engrandecido, ensanchado, dispuesto hacia una ontología de lo posible. Un realismo que inventa desde y hacia la ciudad como objeto ahí, como objeto en el que estamos» (Puelles 2002, 156). 
Pero también, entre las propias, que también llegarían a parar al Rastro, podrían encontrarse

las cosas que decoraban abrumadoramente el cuarto que fue nuestro en aquel hotel francés. [...] Abandonamos aquí los restos -traje, reloj y botas-de aquellos suicidas que tuvimos la desgracia de ver muertos, aquel ahogado y aquellos dos muertos de bala. No sabíamos lo que hacer con ese recuerdo. [...]

Todo es posible en el Rastro, y en esta posibilidad todo descansa, se va, nos despeja. Se gana así en tranquilidad porque las cosas más obsesionantes, más adheridas, hasta las más esperadas, así se pacifican, se distraen para siempre, sueltamente, desahogando el alma atorada de ellas (GS 1998, 157).

Esa arribada y mescolanza de todo alimenta al eros sin síntesis de las cosas conviviendo en su recíproco extrañamiento. GS antecede también al collage (Ernst 1982, 198-199), pues lo que le incumbe no es simplemente ni sobre todo esto o aquello (que también), sino las configuraciones-en-proximidad.

Lo verdadero es esto $y$ lo otro, y el Todo que forman. Su intuición puede darse también ante la estrechez de un baúl. En un extraordinario pasaje en el epígrafe dedicado a Las cosas del señor Andreu, GS recuerda cómo en cierta ocasión el Sr. Andreu permitió que accediese, siendo niño, a los baúles que se encontraban en su buhardilla. Lo extraordinario del texto merece que lo citemos por extenso:

Estaba ya tranquilo, cuando un día subí a la buhardilla a por cosas, esas cosas admirables e insospechables que se esperan encontrar en los desvanes y sobre las que los niños tienen el derecho de ocupación, porque los padres no las dan importancia, o no las quieren o no saben que estaba allí eso y permiten al pequeño descubridor que sea su dueño. La criada que subía a abrirme refunfuñaba:

¿Qué creerás tú que hay ahí? ¡Cómo no creas que hay un tesoro en los baúles del señor Andreu!...

¿Los baúles del señor Andreu? ¿Qué baúles eran esos? Estuve por no entrar, pero ya no podía retroceder y vi aquellos baúles, aquellos baúles, aquellas cosas que no se me habían de olvidar nunca. ${ }^{13}$ Uno era chato y largo y parecía el ataúd en que él estaba extendido y seco. El otro estaba entreabierto porque no le cabían las cosas dentro; le levanté la tapa y vi dentro cosas crueles y antipáticas: un ros, una espada, y sobre todo vi una dentadura postiza y una manecita de marfil, de esas para rascarse, de tan sucio, de tan superfluo, de tan materialista cometido... Huí escalera abajo, [...]

13 Esto es lo que luego configurará el Ello ramoniano (GS 1988-4, 179). 
Durante algún tiempo tuve olvidado al señor Andreu y sus cosas, pero cuando un día descubrí el Rastro volví a ver las cosas del señor Andreu y aun las sigo viendo, las veo siempre que voy, las elige mi instinto con caprichos y fijezas incomprensibles.

Aquello -me dice mi mirada dándome una lección muy fatua-, aquello es del señor Andreu... Y aquello... Y aquello...

Yo ya, impávido, me fijo en esas cosas que no sé por qué van a ser del señor Andreu y comprendo mejor el alma, los rastros privados del Rastro... ¡Sólo no soporto el ver una manecilla rascadora, esa garrapata suave, ese aparato ruin, simiesco, sucio, procaz, escarabajeante, escalofriante, abracadabrante! Es la única superstición que me es irresistible. ¡Cómo me arañó aquella que me ofreció como con sarcasmo el cínico trapero, metiéndomela por los ojos y ponderando el que era de ahití y de marfil! (GS 1998, 130-131).

De cara a la praxis de extrañamiento, lo decisivo no es sólo el poder de la arribada de todo o de cualquier-cosa sino, claramente, esta experiencia de encuentro sorprendente e interrogativo. Y del mismo modo que el joven integro es un personaje de El Rastro, también lo es, a pesar de su anecdótico nombre propio, ese "Sr. Andreu" que concentra toda la fuerza de lo inquietante del Rastro y viene a ser como el Gran Otro Desconocido del que proceden las cosas. Es así como "Cualquier-cosa" y "Cualquiera" se dan la mano.

\section{DeSFuturición. SiC TRANSIT. EXTRAÑo MiÉRCOLES DE CENIZA}

La praxis de extrañamiento que lleva a cabo GS en el Rastro afecta, sin duda, a la temporalidad. Si el futurismo pensó el advenimiento desde el futuro como irrupción desmedida y necesario destrozo del pasado, para GS el futuro que está en juego es casi un anti-futuro, pues se trata del extrañísimo futuro del ir-a-parar-al-pasado, tan amplio y no menos profundo que el futuro de lo que viene al Presente. Ultimo Futuro, más último que el último futuro de lo que haya de venir. Pero no habrá ya vendaval alguno ni debacle, ni velocidad desmedida ni coche de carreras ni sirena de fábrica ni traqueteo de máquinas. Moderno y madrileño cielo de amigas-nubes baudelaireanas (Baudelaire 1994, 51) a ras de tierra-y-rastro que deja paso a los residuos. En este sentido, la praxis de extrañamiento traduce el distanciamiento descreído de GS respecto al futuro soberbio, encrespado y belicoso del futurismo. Más allá de cualquier compromiso cronológico, lo que habría de propiciarse sería la apertura ucrónica (y utópica) de la brecha de lo Nuevo y la Invención ipero a partir de lo desechado, lo arruinado o desahuciado! Para GS lo realmente decisivo no es el futuro, sino lo Nuevo ${ }^{14}$ que podemos hacer a partir de lo viejo, pero no,

14 En 1931, en el «Prólogo» a Ismos, GS realiza una auténtica apología de lo 
en absoluto, como lo hace la tradición, que siempre reivindica la memoria del pasado, sino en dirección a lo innovador insólito, inaudito y extraño.

Así pues, no sería descabellado considerar que El Rastro, en lugar de acreditar alguna vanguardia sin más, parece más bien avalar la vanguardia de la retaguardia de las cosas que quedan al final: desgastadas, cansadas, alicaídas, casi abandonadas, venidas a menos después de su larga jornada. Aquí no hay cabida para ninguna ideología de progreso, pero tampoco para alguna nostálgica laudatio del pasado. ${ }^{15}$ La vía de la praxis de extrañamiento que prosigue el Rastro es la del deshacerse para rehacerse, pero sin un telos mundano; todo lo más, si fuese necesario, un telos de trascendencia fuera de este mundo -tal vez un instante de cielo poético. Por eso, al mismo tiempo que busca rehuir todo desánimo, El Rastro es inevitablemente, a pesar de todo, un monumento extraordinario, al mismo tiempo amable y desasosegante, a la Vanitas humana o un impresionante espacio-tiempo para el Miércoles de ceniza no tanto de las cosas cuanto del ensoberbecimiento del futuro. ${ }^{16}$ Lo único imprescindible es que el Rastro no sea un cementerio. Sin vida ni muerte por entero o «en propiedad», las cosas del Rastro son, en verdad, como fantasmas (Maddox 1997, 164).

Valga como ejemplo del distanciamiento des-futurizador ramoniano el extrañamiento respecto al coche de carreras de Marinetti a través de un «coche familiar» yacente, desvencijado, del que dice GS, meditabundo y genial:

Ahí estará, como otros han estado antes, mucho o poco tiempo, hasta que un día desaparezca sin saber cómo, pues una cosa que nos ha faltado ver aún con nuestra asiduidad, ha sido el ver entrar o salir estos coches. Sobre todo hubiésemos querido verles salir enganchados a unos caballos de Alberto Durero, unos caballos silenciosos con cascabeles sin badajo, unos caballos blancos que con una fantástica ligereza les deben llevar a las regiones blancas (GS 1998, p. 134). ${ }^{17}$

Nuevo, pero se trata de la Innovación y de la Invención (GS 1988-2, 113).

15 Ciertamente, de las cosas ya no importa si tienen futuro, pero tampoco su pasado, en el sentido de un gran pasado «condecorado» en un Museo o tienda de Anticuario.

16 Pieza imprescindible en los totalitarismos del siglo XX, comenzando por el fascismo. En Ramón no se trata de la alabanza monumental de las cosas del pasado (Vattimo), sino de la motivación de las cosas sin-presente y sin-futuro para la brecha de lo Nuevo y la Invención.

17 En el Ex-libris de 1931, GS recuerda este pasaje del «coche familiar» y lo utiliza como ejemplo de hasta qué punto el libro siempre necesita ser infinitamente revisado. Respecto a los caballos blancos, propone GS añadir «trasijados», es decir, muy flacos, «¿porque habrá algo que represente con más magrez los caballos espectrales que esa calificación?»(GS 1998, 796-797). 
¡Insuperable surrealidad! Aunque sin futuro en este mundo, el poeta reserva al coche arrumbado, decrépito, un novum imaginario, de modo que henos aquí convocados poéticamente hoy, más de cien años después, ante su renovada presencia. Al elegir el portabotellas y (pretender) firmarlo, la praxis de extrañamiento duchampiana era, en el terreno genuinamente artístico, más cortante y seca, y abocaba deliberadamente a la experiencia de un novum artificial y absurdo en el que la cosa cualquiera se torna potencial nadería con vistas a transgredir y desestabilizar lo que deba considerarse «arte». Del mismo modo (hablaré luego de ello), la dialéctica denigrante batailleana respecto a la baja seducción no busca trascender la parte «sucia» o abyecta, sino perturbar a la parte encumbrada, humillándola. Por el contrario, el extrañamiento ramoniano -de aquí la ternura- aspira a redimir/reanimar las cosas elevándolas extático-poéticamente ¡Qué no habría podido decir GS sobre el portabotellas de Duchamp o sobre el dedo gordo del que hablaba Bataille!

Finalmente, como magistral y abrumador colofón de lo Posible (y casi como reproche radical a la puerilidad futurista) dirá GS que «en el Rastro habrá pronto, caído y tranquilo, un aeroplano, y ese hombre automático que prepara la Civilización vendrá al Rastro también» (GS 1998, 156-157).

Así como el mero futuro de las cosas recién estrenadas, nacidas en la fábrica o expuestas en la tienda, etc., dejan paso a un novum diferente, así los paseantes que elige GS como protagonistas del Rastro están abiertos a lo nuevo, pero ¡no les importa nada la moda! -amiga de la muerte-, sino la energía crítica y extrañante de la "autenticidad" que el Rastro exige. De aquí la figura no futurizadora, sino innovadora, de los jóvenes íntegros, a que antes me referí.

Por otra parte, qué duda cabe de que el potencial de extrañamiento de las cosas viejas es enorme respecto al destino material, burgués o simplemente pragmático y capitalista de las cosas. Como ha mostrado Hal Foster, la importancia de lo anticuado en el surrealismo conecta con que «lo anticuado es siniestro [...] como imágenes y objetos familiares que se vuelven extraños a través de una represión histórica, como cosas heimisch (familiares) del siglo XIX, que vuelven como unheimisch (siniestras) en el siglo XX» (Foster 2008, 213). El recurso a lo anticuado funciona como un détournement retórico del régimen propio de la mercancía en el horizonte capitalista. No se trata de «romantizar», sino de alcanzar una perspectiva crítica y terapéutica. Como dice Foster, «invocar formas anticuadas [...] es una manera de promover una crítica inmanente y doble de la cultura burguesa, negándole su pretensión a lo natural y eterno, abriéndola a su propia historia, y de hecho, a su propia historicidad. Efectivamente, explota la paradoja de que esta cultura, hechizada por la mercancía, no tiene historia alguna» (Foster 2008, 259-260). ${ }^{18}$

18 Cf. Marinas 2001. 


\section{Des-Familiarización. El GRAN EXTRAÑo (DESCONOCIDO)}

Desposeídas del futuro «ideal» que proclaman las cosas recién estrenadas, se diría que las cosas del Rastro tienen biografía, y es cierto, pero una biografía desconocida. De lo que se las ha desposeído es de su hogar. Lo tuvieron (y un dueño o propietario), pero en la situación fenomenológico-hermenéutica en que son acogidas por el éxtasis poético ramoniano han quedado desahuciadas. En verdad sólo les resta su eidos avejentado -pero eidos, al fin y al cabo. Lo que no es poco. Y sin embargo, ya no acogidas confortablemente o atrapadas opresivamente por un hogar y un propietario, y presentándose sin apenas memoria, sin ninguna historia concreta que contar, en cierto modo ¿no es como si fuesen más ellas mismas? Son tan sólo, y sobre todo, lo que son: aquí una navaja, allí una pluma estilográfica, o un dedal. Y lo son tanto, casi pre- o post-hermenéuticamente, que quedan liberadas para una posible segunda vida. Sin la mano que lo usaba con mayor o menor habilidad, el abanico parece ganar nueva vida con ser tan sólo un abanico, pero con todo lo que de sí pueda dar un abanico, más allá de lo que el destino parece marcarle como su única verdad funcional. El jarrón chino ahora podrá respirar aliviado, cansado como quizás estaba de soportar aquel triste salón en continua penumbra, tan ajeno a la lejanísima, misteriosa y legendaria China. Las cosas quedan sin hogar, ciertamente, pero también -quién sabe- libradas de su cárcel. Después de todo, entre poseer un eidos y tener un hogar, aquel puede resultar que brinde más libertad -o al menos holgura. Respecto a su eidos, cada cosa es tan sólo una más y esto desahoga, sin que el eidos impida a cada cosa su más extrema e irreductible singularidad... Por su parte, el hogar no sólo acoge, sino que aposenta y agobia. En muchos pasajes de El Rastro es esto lo que GS da a entender. Fuera del bazar y del hogar una plancha será convertida por Man Ray (acompañado de Satie) en algo así como un Cadeau, que solemos describir (porque así lo vemos), aunque no sea una descripción adecuada, como una «plancha con clavos».

No se trata únicamente de que las Cosas del Rastro hayan sido desahuciadas del Hogar. Es que, por lo general, han llegado al Rastro siguiendo el camino siniestro o malhadado que les propusieron la muerte, la ruina, la desgracia (lámparas de minero, cunas (GS 1998, 108 y 184, respect.), el delito (en el caso de las navajas, GS 1998, 106) o la «mala vida»... Por eso, a veces, las distancias de extrañamiento que recorren las cosas del Rastro son enormes, aumentando así, por otra parte, su fuerza de imantación, verdadera semilla de sabiduría. Por ejemplo, respecto a los muñecos:

Los muñecos de cuerda son los más impresionantes. [...] Se mueven aún. ¡Pero cómo! Como atacados de epilepsia, disparatados, como con enormes dificultades, haciendo grandes esfuerzos, con algún miembro paralítico, incurable. ¡Qué dolor 
aquel muñeco saltimbanqui que tan maravillosas volteretas debió dar en sus buenos días y que aquel energúmeno vendedor del Rastro se entretenía cruelmente en dar y volver a dar cuerda, viéndole sufrir tanto al intentar dar una voltereta que le fallaba cayendo sobre un hombro y dando impotentes vueltas de anguila sobre el suelo, mordiendo el polvo sudoroso y resollante como un soldado herido que aspirase a levantarse con dignidad! Algunos de esos muñecos mecánicos enseñan sus alambres, dando un feo y desilusionante espectáculo de cadáveres que enseñan su anatomía en las mesas de disección. Espectáculo más deplorable en los muñecos porque queda su cabeza viva y parlante sobre su cuerpo tumefacto.

Todos estos juguetes usados parecen contener un misterioso espíritu demasiado humano. Aquí parecen haberse sobrepasado y estar más allá de la moral y el pensamiento corriente.

Se piensa con pavura en el niño que los compra como si en ese niño pudiesen surgir inquietudes atrabiliarias, raras predisposiciones, deseos insaciables, desequilibrios torpes y geniales; ¡qué sé yo qué cosas!

No en vano viven estos muñecos esta vida intensa, sabia y vidente, y no en vano han visto la noche a solas en un desván.

Yo veo al niño que ha comprado aquel inolvidable muñeco sentado en un taburete y que moviéndose parecía querer decir algo trascendental, le veo tornarse viejo, intencionado, grave, jugar con una extraña lentitud con él y quedársele mirando largos ratos, hasta que un día, abandonándole de pronto y presa de una resolución tremenda, le dice á su pobre padre que quiso comprarle un juguete bueno y caro, un juguete de príncipe con poco dinero: Yo quiero ser un sabio (GS 1998, 149-150).

A medio camino entre lo real, lo demasiado real y lo real-ajado, el eidos viejo y lo fantasmal, las cosas decisivas de la experiencia del Rastro son cosas/ útiles ante los ojos y a la mano, si nos vale decirlo al modo heideggeriano, sólo que más ante los ojos y, eso, sí, a-la-segunda-mano (cf. Heidegger 2009, cap. III, sobre la mundaneidad del mundo). Por eso son más densas y potencialmente enigmáticas. Muchas meditaciones de GS se orientan en este sentido, pero no hay intento alguno detectivesco de indagar ni reconstruir, pues la verdad y el ser de estas cosas del Rastro no depende ya de su anterior vida, sino del resto de su nueva vida. La praxis de extrañamiento estriba en mantenerse en la incertidumbre de ese Gran Extraño que hizo suya la cosa y luego se esfumó.... No se trata, como en la analítica heideggeriana, del usuario formal al que remite el útil (la barca remite al barquero, la red al pescador, etc.), sino del que «vivió» la cosa, se la apropió o la «domesticó». Desahuciadas, las cosas dejan que la imaginación vuele. Por ejemplo, los espejos del Rastro son espejos

sin angostura. Perdieron sus sordideces privadas mirando al cielo en el carro que los trajo [...] Se siente una rara efusión ante estos espejos, un vértigo extraño. La 
efusión y el vértigo de nuestra vida que se va yendo en un espacio tan imaginario. Son transmigradores, están llenos de trashumancias, de fugas, de desatadas facilidades. Un irse pancho y ancho hay en ellos (GS 1998, 189).

Este nivel III de la praxis de extrañamiento (los dos primeros son la deslimitación y la desfuturición) es relevante en la medida en que perturba interiormente lo que Heidegger llamó hacia 1923 hermenéutica de la facticidad, ${ }^{19}$ de modo que siendo esa hermenéutica sobre todo cotidiana, incluso íntima y entrañable, sin embargo, en el Rastro queda perturbada por una incertidumbre que parece sustraer el ser a las cosas -si hubiésemos de seguir a Heidegger.

\section{Desfuncionalización. Por UNA SEGUNDA VIDA}

Al margen de la dialéctica en virtud de la cual el útil domina incluso sobre lo inútil y en el fondo no hay mejor manera de someterse a lo útil que toparnos a sensu contrario con trastos (en el trastero) o con lo roto e inservible, GS no espera de sus cosas del Rastro que cumplan, hayan cumplido o vayan a cumplir su función correcta en una totalidad o plexo de conformidad de acuerdo a la intrínseca funcionalidad del útil (Heidegger 2009, § 16). Excluyendo todo abuso

19 En Ontología. Hermenéutica de la facticidad, Heidegger se esmera en hacernos comprender en qué medida las cosas se dan pre-comprensivamente en medio de la ocasionalidad del existir, de modo que cada cosa está como investida o impregnada por el existente, no porque éste haya subjetivado reflexivamente las cosas, sino porque al apropiárselas comprensivamente las ha hecho existencialmente suyas, y de este modo las ha hecho ser. Estamos casi en las antípodas de la cosa anónima y abstracta, o incluso simplemente funcional. En su demorarse en la cotidianeidad, la hermenéutica de la facticidad accede a un singularizado mundo familiar en el que las cosas son justamente ese modo de ser en que son ellas, esas y no otras, con esa vida adosada y no otra, cosas «punctuales» (que diría Barthes), «punzantes», de imposible studium. Lo que importa no es la mesa en general, ni lo que pudiéramos hacer con ella como esta mesa, pero desvitalizada, ni cómo podríamos describirla como con tal o cual función (como mesa de escritorio, de comedor o de costura). Es decir, no se trata, de ningún modo, de una mesa «objetiva», sino inserta en la cotidianeidad. Dice Heidegger: «Esa es la mesa, así es como está aquí en la temporalidad de la cotidianeidad, y como tal volverá a aparecer acaso dentro de muchos años, cuando se la encuentre volcada en el suelo, retirada e inutilizable, como tantas otras «cosas», por ejemplo, un juguete, estropeado y casi irreconocible - es la propia infancia. En la bodega, en una esquina, se tienen de pie un par de viejos esquís; uno de ellos está roto; lo que allí hay no son cosas materiales de distinta longitud, sino los esquís de cierta época, de aquella carrera temeraria con éste y con aquél. Este libro que tengo aquí es un regalo de X; éste de aquí me lo encuadernaron en tal imprenta; este otro habrá que llevarlo a encuadernar; ¡ a este otro le he dado tantas vueltas!; ése de ahí fue una adquisicón inútil , una decepción; ese otro tengo que leerlo todavía [...]. Tales son los rasgos del ocurrir. Ahora habrá que preguntarse cómo constituyen el existir del mundo (Heidegger 1999, 116). 
utilitarista, lo que busca GS es una vía diferente de acceso a no se sabe bien qué (surrealidad es la clave, sin duda, pero aún no tiene ese nombre en 1914), y para ello hay que desutilizarlas (Moreno 2005). Duchamp fue en esta praxis de extrañamiento el gran maestro y provocador. Todo dependería del intento de hacer estallar interiormente al útil atrapado en su utilidad, deshaciendo su "razonabilidad" mundana, de modo que pudieran abrirse múltiples posibilidades que sin negar al útil -un abanico sigue siendo un abanico- serían capaces de desestabilizar esa soterrada cordura a la que usualmente el utilitarismo/ pragmatismo se confían. Para GS, como luego para dadaístas y surrealistas, lo decisivo y primero no era el útil, sino la Cosa justamente en su extrañeza, de modo que lejos de pasar de largo, resultaría imprescindible aprender a detenerse y dejarse conmover también y quizás sobre todo por las cosas ante las que no se sabría decir a qué utilidad sirven y ni siquiera a veces qué son (GS $1998,119) \ldots$ y rescatarlas precisamente por esa incertidumbre, que hiere desde dentro al útil como categoría general de comedida clasificación objetológica. Así, por ejemplo -serían cientos de ellos-GS se deja seducir por los

paraguas rotos, hechos una birria [...] Paraguas sin tela, en esa actitud desolada, grotesca y desplumada de los pájaros en esqueleto, un esqueleto sutil de finos y grandes y puntiagudos murciélagos como macabros ornamentos de brujas... ¡Oh desolación, flacidez, vencimiento, despropósito, desaire el de un paraguas de desnudo varillaje, falto de sexo! Porque ¿era paraguas o sombrilla? ¡Oh tragicomedia! (GS 1998, 112-113).

...pero también se extasía GS ante máquinas definitivamente rotas a las que les falta tal o cual pieza imprescindible y de las que verdaderamente no se sabría decir qué son (GS 1998, 235-238). El Rastro no es un paraíso de lo inútil, ciertamente, pero sí de la jubilación poética de las cosas. Como dice César Nicolás,

a cada paso, Ramón disloca y subvierte el objeto industrial. Al sacarlo de su contexto, al vivificarlo mediante técnicas animistas, al fundirlo con otros en imagen, destruye su valor utilitario, su carácter de mercancía. Esos objetos tienen alma -y al tiempo que los humanos se cosifican, ellos se transforman y agrandan en nuestra percepción (Nicolás 1998, 44).

El propósito de GS es el de la fecundación poética por medio de ese Como... que le fascinaba y del que decía en 1917 que es «la palabra más exaltadora de que disponemos [...], se pronuncie o se calle. Por ella da su medida la imaginación humana y se juega el más alto destino del espíritu» (GS 1988-3, 127). 


\section{DES-IDEALIZACIÓN Y BAJA SEDUCCIÓN}

En cierto modo, la praxis de extrañamiento parece contribuir a convertir las cosas del Rastro en cosas desalmadas, más de lo que ya han llegado a convertirse en tales por haber ido a parar allí. Y, sin embargo -en esto consiste también y quizás sobre todo la praxis de extrañamiento-, justamente se trata de reanimar las cosas o darles vida... incluso por medio de lo que en ellas parece atraer menos a un deseo rutinario o vulgar. Hasta tal punto debe llegar la ternura.

Ni que decir tiene que la perversión del desvío errático o la deriva ya llevaban tiempo haciendo estragos - quiero decir: trascendiendo- en la experiencia poética más radical. Como el poeta-albatros de Baudelaire (Baudelaire 1992, 35), así también las cosas rutilantes-de-consumo desfallecidas en el Rastro son como albatros caídos. E incluso podría pensarse que si bien aún guardan su distancia frente a la carroña de la amada, apelan al poeta para que éste les preserve algún resto de la forme et l'essence divine (Baudelaire 1992, 78). En cierto modo, podría decirse que el Rastro viene a ser como aquel dedo gordo del pie que fascinaba a Georges Bataille, pues le servía para, en una dialéctica denigrante, pensar a fondo las posibilidades de experiencia en base a lo que Bataille denominaba baja seducción (Bataille 2003-2, 44-49). La praxis de extrañamiento en el Rastro requiere un amor verdadero que rescate lo marginal, barriobajero, bajetón, humilde y ruín (GS 1998, 79) contra o al menos con el telón de fondo de la Ciudad falsa, rutilante y vil. El Rastro no es ni museo, ni bazar de antigüedades, ni lugar de turismo (GS 1998, 76-77). Hay que morder el polvo para jubilar sus cosas, aunque no reúnan ya glamour alguno, ni belleza, ni prestigio..., estando todo en el Rastro como fragmentado, desperdigado, en proceso de disolución, en una suerte de dilatada despedida. Más que nadie, el poeta sabe (y por eso es poeta, mucho más que por la destreza en la rima y en la imagen bella), que es necesario descender a lo más bajo para ascender inequívocamente o sublimar, intentando dar a tan pobre apariencia un sentido sublime (Genet 1988, 37-38).

El Rastro de GS se acerca honestamente al Rastro, muestra sus zonas siniestras, sórdidas, no rehúye presentar lo que tiene de detritus, pero al mismo tiempo le atrae la combinación de su vigor vitalista y su laxitud frente a todo deber. La diferencia entre la desidealización de GS y la de Bataille estriba, entre otras razones, en que Bataille quiere sobre todo denigrar lo encumbrado, mientras que GS quiere sobre todo enaltecer lo bajo (que lo encumbrado impone como «bajo»). En otro texto de Bataille sobre la baja seducción, como es El lenguaje de las flores (Bataille 2003-1, 21-28), se acomete una praxis de extrañamiento de la atractiva belleza de la flor atendiendo al estiércol, las raíces, etc. Aquí es al revés: es la ciudad la que hace posible el Rastro como Pozo y Estrella, o Pozo y Flor. «Vueltos de este modo hacia el Rastro, no vemos 
sino un pozo oscuro y a una altura inconmensurable sobre ese pozo algunas estrellas. Ha oscurecido de pronto, de un modo súbito y vehemente. Todo el pasado de la ciudad está ahí, en ese pozo. No es más trascendental la historia, tómese como se tome» (GS 1998, 251).

\section{EXTRAÑAMIENTO Y POSIBILIDAD DE DESHACERSE / DESASIRSE}

«¡Oh, si llega la imposibilidad de deshacer!». Tales eran «las siete palabras» de GS desde muy pronto, sin que sea evidente (o al menos sin que sea unívoco) su significado. A ellas les había dedicado un extraordinario texto, muy crítico, titulado «Mis siete palabras» en 1910 (GS 1988-1), en el que se lamentaba de la institucionalización de todo y de que viviésemos presos, «cumpliendo nuestra prisión en nuestras casas, por la ciudad, en nuestras excursiones y hasta en los viajes más lejanos» (GS 1988-1, 85) y «consintiendo esta alambrada que prospera» (GS 1988-1, 87). En 1910 «deshacer» significaba que se deshiciera todo eso que nos consume atrapándonos, solidificándonos, etc. En un añadido a El Rastro en la edición de 1931, explicaba GS que el deshacer alude a lo que se dice en el pasaje del Nuevo Testamento en referencia a la importancia de que se deshiciera el grano de mostaza para que produjese cosecha, añadiendo GS que «lo sabio y lo justo y lo misericordioso y lo divino es deshacer y hacer de nuevo para deshacerlo cuando pueda interrumpir la constante evolución que es necesaria a las vidas duraderas» (GS 1998, 701). Es en este horizonte ambiguo donde debe ubicarse la praxis de extrañamiento a la que vengo refiriéndome. Para consumarla, no debe olvidarse el auto-extrañamiento existencial. Hay que liberarse de las cosas... pero precisamente no sobre todo porque ellas, las cosas, envejezcan mal, etc. Hay que deshacerse de las cosas precisamente en la medida en que en ellas «se hacen» y a ellas se aferran el límite, el futuro, el hogar, la ciudad, la utilidad... He aquí, a la altura de 1914, una de las claves del vitalismo ramoniano, en el que quizás no se propondría un nietzscheano vivir junto al volcán (Nietzsche 1988, 208), sino más un más sencillo, sereno y hechizado vivir junto al Rastro.

La apuesta de praxis de extrañamiento de GS es clara: alcanzar un espaciamiento o liberación, otra vida, en otra parte. Pero como dije, no se trata del futuro, sino de la juventud íntegra y de lo nuevo como invención, también en la hora matutina o vespertina de los Trastos, Restos y Escombros. Hay mucho que despejar para que el fruto de lo extraño sea posible. Ha sido preciso deshacerse del futuro rimbombante $\mathrm{y}$, por supuesto, de la ilusa amabilidad de un progreso pueril; ha sido preciso deshacerse de las cosas mondas y lirondas, cosas usuales y relucientes del consumo, y salir de la ciudad, vil y tan interesada como poco interesante. Ha sido necesario des-utilizar, des-funcionalizar, querer los trastos y restos del Rastro de modo que ya no se nos ocurriese seguir como siempre usando la plancha para arrasar arrugas, dándole cuerda al reloj 
para simplemente saber la hora o para que sonase el despertador como cada día. Tras des-hacer, ¡no se trataba de re-poner! Las cosas del Rastro se irán para siempre - tan singulares son (y GS se lamentará de que algunas se le hayan escapado, sin saber a dónde fueron a parar (GS 1998, 232-235). Ha sido imprescindible deshacerse del Hogar y de nuestro conocimiento entrañable (o rutinario) en y por el que las cosas nos resultan familiares (y anodinas). Y ha habido, desde luego, que des-hacer el ideal, descender al «dedo gordo del pie» de la ciudad, hasta esta especie de asilo donde las cosas, casi a punto de convertirse en excrementos o basura, se reservan para que GS les regale -a ellas, con su rarísimo conatus essendi- un minuto último de gloria y una eternidad de negro sobre blanco. ¡O acaso no se nos han hecho eternas, por recordarlas, las extrañísimas alas de ángel que GS titubeó en comprar y que luego lamentó no haberlo hecho, porque le recordaban demasiado a un artilugio ortopédico! (GS 1998, 705-706). De ganar para ellas una segunda vida surreal: de eso se trata. Y del milagro del surgir de la «rosa» de la surrealidad sobre un paisaje de ruinas y de supuesto fracaso y decadencia. Resulta fascinante que en GS se anticipe el movimiento que conducirá desde la demolición dadá a la repoetización surrealista del mundo. Ya había sucedido antes, ese movimiento, en un madrileño de apenas veintiséis años, que jugaba a su manera a parecerse al Angel de la Historia que comentaba Walter Benjamin, que se dirige al Futuro mirando a la Historia en sus despojos y ruinas.

Pero no se propone mensaje alguno apesadumbrado. Por el contrario, se nos invita a fortalecernos, rejuvenecernos, «jovializarnos» en esa múltiple praxis de extrañamiento que sólo el Rastro podría ayudarnos a experimentar, a modo de lanzadera o disparadero existencial, crítico y poético aunque fuese desde un pozo oscuro bajo un cielo estrellado.

Lo advertía antes. Por supuesto, finalmente -era de esperar- la praxis de extrañamiento lleva consigo des-hacernos de nuestras cosas y de «lo nuestro y nosotros». Extrañarse, en el fondo, también de las cosas propias y de uno mismo.

Desgraciado del que no haga esta cesión de sus cosas, regalando hasta el objeto que le sea más caro, caro como una mujer. No sabrá lo que es esa fluidez espiritual que se siente después de ese sencillo arrojo. No poseerá esa mirada corriente y clara, como la del agua que no tiene nada, que lo abandona todo. [...]

¡Cuánto ganamos en espacio interior para el baile íntimo!

Es grato esto, sobrepone, es consolador saber que hay un sitio en que poderlo tirar todo y donde todo queda a sus anchas, sin agobio ni dura memoria, sin atranco, sin purgatorio (GS 1998, 212).

Vaciado, GS vuelve desganadamente a la ciudad y al hogar. De este modo concluye El Rastro. Lo extraño y marginal se tornó amable, íntimo, entrañable, y ella, la ciudad, quedó extrañada. 
¿Ir a casa? Hasta por nuestra casa se siente falta de afición, y no una caprichosa falta de afición, sino una indubitada falta de afición.

Venimos desde la reformación del mundo por la destrucción llena de cordura y sensatez del tiempo trivial -no por las guerras ni los cambios de civilización-, venimos del solar lleno de buen acuerdo para la nueva arquitectura, y encontramos el mundo aún construido a su manera, idiota, insensato, rencoroso, rudo, enfático, insostenible pero sostenido, enemigo, obsceno y atrabiliario. Las tiendas nos parecen vulgares, brutales, despreciables, usurarias, de una risible seriedad y reconcentración al lado de aquellas que hemos visto abiertas a todas las ideas y a todas las transacciones [...].

Hasta contra nuestras propias empresas nos domina una rebeldía incombatible, tan suave y sutil, que se nos impone como se nos podría imponer el espíritu de un Dios existente de verdad.

Lo que aun hay de enemigo nuestro en nosotros se intenta burlar de que esta especie de doctrina interior que nos llena la haya fomentado el sencillo paseo por el Rastro, tan aparentemente chabacano y accidental, pero una sólida seguridad mata la burla. Verdaderamente en el sexo de esos escombros nos hemos esparcido y encalmado como sólo lo podríamos conseguir en la bella ciudad futura, hija del arrepentimiento sumo y dada a los transportes máximos (GS 1998, 253-254).

La praxis de extrañamiento conduce finalmente a este vaciamiento liberador (Moreno 2007). No sé si sería demasiado atrevido - no lo haré aquíestablecer algún contacto con la experiencia heideggeriana (en torno a 1929) de la angustia (Heidegger 2000, 98 y ss.) o del aburrimiento (Heidegger 2007, Primera parte, caps. II-IV) por lo que a sus efectos se refiere. Hacia el final de El Rastro, el deshacerse vira hacia el desasirse de las cosas propias. Sólo así podría cumplirse lo que podríamos llamar, con permiso de GS, la Ley del Rastro, que invita, contra lo que cabría esperar de una Ley, al más radical Des-ahogo, fuera de presiones y límites, prestigios y fines. A propósito de la experiencia que se alcanzaba en la angustia, que deja en suspenso el ente en su totalidad, Heidegger hablaba de una suerte de calma hechizada [eine gebannte Ruhe] (Heidegger 2000, 101). De eso se trata también finalmente en GS. Junto con las cosas, acercándose y al mismo tiempo despidiéndose de ellas, el paseante del Rastro no se acerca tanto a la Nada (aunque también: a través de la pequeña nada, muerte o desaparición singulares de cada una de las cosas) cuanto a la posibilidad de una Segunda Vida, quizás más decisiva, para GS, que el Ser/Nada que no se deja confundir con nada. Tal es la extraordinaria ética que se desprende del Rastro. Quién sabe si lo que se juega en este deshacer/ deshacerse-de/desasirse/desahogarse a los que invita la praxis de extrañamiento no es, en el fondo, un sentido para el existente humano en el horizonte de una 
trascendencia de la que lo poco que sabemos es que se parece al inspirado desvivirse del poeta.

\section{Despedida. Des-teXtualización. El rastro eXCede a el rastro}

Deshacerse de uno mismo, extrañarse, distanciándose uno hasta de sus propias cosas, pero también, al fin, incluso des-hacerse del propio Texto, destextualizar(se). En 1931, con ocasión de la segunda edición de El Rastro, GS escribió «Ex-libris», texto asombroso, por su actualidad, que da rienda suelta al cuestionamiento, por parte del autor, de lo que significa el acto de escribir y la precariedad de lo Dicho frente al Decir y, sobre todo, frente a lo que queda en las afueras de lo escrito, en lo Infinito e Indecible, tal que la escritura se presenta como una tarea inagotable. Aquella calma hechizada se torna silencio embelesado (Moreno 2016). La Obra debe, también ella, deshacerse, presentarse ausentándose. Es necesario deshacerse de la letra, por su peligro de ser letra muerta o por pretender imponer con frecuencia que todo se rinda a sus pies. Sólo hay en verdad afuera del libro... Pero éste es otro asunto, y otra extrañeza, de la que nos sería imposible ocuparnos aquí.

\section{REFERENCIAS BIBLIOGRÁFICAS}

BATAILLE, G. 2003-1: «El lenguaje de las flores», en La conjuración sagrada. Ensayos (1929-1939). Buenos Aires: Adriana Hidalgo Editores, pp. 21-28.

BATAILLE, G. 2003-2: «El dedo gordo», en ibid., pp. 44-49.

BaUdelaire, Ch. 1992: Las flores del mal, Barcelona, Círculo de lectores.

BAUdelaire, Ch. 1994: Pequeños poemas en prosa. Madrid: Cátedra.

BLANCHOT, M. 1970: «El pensamiento y la exigencia de discontinuidad», en El diálogo inconcluso. Caracas: Monte Avila Editores, pp. 27-37.

BRETON, A. 1974: Introducción al discurso sobre la poca realidad, en Apuntar del día. Caracas: Monte Avila.

BRETON, A. 1992: «Situación surrealista del objeto. Situación del objeto surrealista», en Manifiestos del surrealismo. Barcelona: Labor, pp. 271-308.

BREton, A. 1997: Nadja. Madrid: Cátedra.

CLIFFORD, J. 1995: «Sobre el surrealismo etnográfico», en Dilemas de la cultura. Antropología, literatura y arte en la perspectiva postmoderna. Barcelona: Gedisa, pp. 149-188.

DERRIDA, J. 1994: «Deconstruir la actualidad», El ojo mocho (Buenos Aires), 5, pp. $12-24$.

ERNST, M. 1982: «Más allá de la pintura», en Escrituras. Barcelona: Ediciones 
Polígrafa.

FOSTER, H. 2008: Belleza compulsiva. Buenos Aires: Adriana Hidalgo.

GENET, J. 1988: Diario del ladrón. Barcelona: Seix Barral.

GS / GOMEZ DE LA SERNA, R. 1988-1: «Mis siete palabras (Pastoral)», en Una teoría personal del arte. Antología de textos de estética y teoría del arte (ed. de Ana Martínez-Collado). Madrid: Tecnos, pp. 84-96.

GS / GÓMEZ DE LA SERNA, R. 1988-2: «Prólogo a Ismos», en Una teoría personal del arte. Antología de textos de estética y teoría del arte, en ibid., pp. 108-115.

GS / GÓMEZ DE LA SERNA, R. 1988-3: «Prólogo a Greguerías (1917)», en ibid., pp. 124-159.

GS / GÓMEZ DE LA SERNA, R. 1988-4: «Las cosas y el ello», en ibid., pp. 173-200.

GS / GÓMEZ DE LA SERNA, R. 1998: El Rastro, en Obras completas III (Ramonismo I), El Rastro, El circo, Senos (1914-1917) (edición de Ioana Zlotescu y prólogo de César Nicolás). Barcelona: Círculo de Lectores/Galaxia Gutenberg, pp. 71-254.

GONZÁlez AlVAREZ, J.M. 2002, «El vanguardismo de El Rastro. El "ramonismo" como vanguardia», Boletín Ramón n. 5, pp. 56-59 (online: http://www. ramongomezdelaserna.net/BR5-PDF.PDF).

GOYTisolo, J. 1998: «Lectura del espacio de Xemaá-El-Fna», en Makbara. Barcelona: Seix Barral, pp. 201-222.

HeIDEGGER, M. 1981: Conceptos fundamentales. Madrid: Alianza Editorial.

HeIDEgGer, M. 1999: Ontología. Hermenéutica de la facticidad. Madrid: Alianza Editorial.

HeIDEgGer, M. 2000: ¿Qué es metafísica?, en Hitos. Madrid: Alianza Editorial.

HEIDEGGER, M. 2007: Los conceptos fundamentales de la metafísica. Mundo, finitud, soledad. Madrid: Alianza Editorial.

HeIDEgGeR, M. 2009: Ser y tiempo. Madrid: Trotta.

HUGHeS, R. 2000: El impacto de lo nuevo. Barcelona: Galaxia Gutenberg/Círculo de lectores.

MADDOX, C. 1997: «El objeto en surrealismo», en El objeto surrealista (con estudio preliminar de E. Guigon). Valencia: IVAM, pp. 164-165.

MARINAS, J.-M. 2001: La fábula del bazar. Orígenes de la cultura del consumo. Madrid: Machado Libros/La Balsa de la Medusa.

montaigne, M. de 1984: Ensayos (3 vols.). Barcelona: Orbis.

MORENO, C. 2005: «L'oggeto in revolta. Saggio sull'intenzionalità estraniata dell" oggetto surrealista», en Fenomenologia e Arte. Immagini e figure riflesse nella filosofia. Milano: Mimesis, pp. 63-75. También «Das Objekt in der Revolte. Versuch über die entfremdete Intentionalität des surrealistischen Objekts», en Phänomenalität des Kunstwerkes. Wien: Mesotes, 2006, pp. 164-179.

MOREno, C. 2007: «Sin objeto. Epojé, vanguardia y fenomenología», Phainomenon 14 (2007), pp. 307-325. También en Investigaciones fenomenológicas 6 (2008), pp. $395-418$. 
MORENO, C. 2012: «Los oídos prestados y el apeiron sonoro. Notas para una filosofía de la música», en Teorema XXXI/3, pp. 193-208.

MORENO, C. 2014: «Lecciones de cosas. Seducción de la facticidad y filosofía primera en José Ortega y Gasset (Seguido de un hipotético encuentro entre Ortega, Gómez de la Serna y Duchamp)», Devenires. Revista de Filosofía y Filosofía de la Cultura, Año XV, núm. 29, pp. 181-215.

moreno, C. 2016: «Márgenes silentes. Palabra excedida y silencio inspirado (Hofmannsthal/Blanchot), a aparecer en Quaderns de Filosofía, Vol. III, n. 1.

NICOLÁs, C. 1998: «La cornucopia vanguardista», en GS 1998, pp. 37-68.

NIETZSCHE, F. (1988): La gaya ciencia. Madrid: Akal.

ORTEGA Y GASSET, J. 1994: «Meditaciones del Quijote», en Obras Completas I. Madrid: Revista de Occidente/Taurus.

PUELLes, L. 2002: El desorden necesario. Filosofía del objeto surrealista, Málaga, Universidad de Málaga.

TOMKIns, C. 1999: Duchamp. Barcelona: Anagrama.

César Moreno-Márquez es Catedrático de Filosofía en la Universidad de Sevilla. 